\title{
Working Futures: The ILO, Automation and Digital Work in India
}

\author{
Filipe Calvão and Kaveri Thara
}

\begin{abstract}
With access to data communication networks and the prevalence of informal work, workers in the global South are rapidly inching closer to confronting the impact of automated or digitally enabled non-standard employment. What are the social and political responses required to face this shifting engagement with the means of automated production and the experience of digital work mediated through privately owned global technology platforms? By examining India's job market, with a focus on the country's information technology (IT) industry, this chapter assesses whether the International Labour Organization's (ILO) focus on labour rights and social protection is suited to addressing the potential for capital-labour substitution and the new ecosystem of software-mediated work. The chapter suggests a new engagement with digital labour, closer scrutiny of unregulated working conditions, and democratic control over tech-enabled digital platforms.
\end{abstract}

What Working Future?

The world faces today a new challenge posed by the combination of jobless economic growth, rising human productivity, and an increase of the available labour pool. In developing economies in particular, the future may not even hold enough jobs for everyone. ${ }^{1}$ It is estimated that by 2030, the global labour

1 This much was intimated by the World Bank's president in a 2016 speech: 'The traditional economic path from productive agriculture to light manufacturing and then to large scale industrialisation may not be possible for all developing countries. In large parts of Africa it is likely that technology could fundamentally disrupt this pattern.' Research based on World Bank data has predicted that the proportion of jobs threatened by automation in India is 69 per cent, 77 per cent in China and as high as 85 per cent in Ethiopia.' 'If this is true,' Jim Yong Kim continued, 'we need to understand the paths to economic growth that will be available for these countries and then adapt our approach to infrastructure accordingly.'

(C) FILIPE CALVÃO AND KAVERI THARA, 2019 | DOI:10.1163/9789004399013_012

This is an open access chapter distributed under the terms of the prevailing CC-BY-NC license at the time of publication. 
force will increase by 428 million workers, the majority of whom will be in low- and middle-income countries (LMCs) in Africa and South-East Asia (ILO, 2017). India's population, for example, is expected to surpass China's within a decade, reaching 1.66 billion by 2050, and ten countries alone are expected to contribute collectively to more than half of the world's expected population increase from 2017 to $2050 .{ }^{2}$ The demographic pressure of a growing labour force, particularly for youth in vulnerable employment in low-income countries, may exacerbate the mismatch between workers' skills and those sought by employers (ILO, 2017, 34), and encourage the competition for the least valuable skills, i.e. skill sets available will become less valuable. If the benefits of this demographic transition depend largely on the ability to employ productively its working-age population, the prospect of a growing labour force outpacing job creation and productivity gains foreshadows a future of widespread joblessness. This challenge is further exacerbated by the job replacement potential of recent developments in artificial intelligence (AI).

Previous waves of mechanisation and automation have led to the creation of redundant or surplus human labour in agricultural and manufacturing jobs. Despite a recent decline in global unemployment rates, often attributed to shrinking labour force participation, few jobs are now immune to computerisation or automation. With AI, in fact, bots, drones, and other intelligent machines are learning to perform autonomous work, identify patterns and predict behaviour, and solve non-routine and cognitive tasks, rendering most human labour potentially automatable at the point when humans are more productive than ever. If developments in robotisation have been mostly confined to developed economies, falling technology costs and the sweeping effects of intelligent software development for non-routine tasks are already impacting low-skilled and low-waged labour as well as high-skilled workers across LMCs. ${ }^{3}$

Speech by World Bank President Jim Yong Kim-The World Bank Group's Mission: To End Extreme Poverty, 3 October, 2016, available online at http://www.worldbank.org/en/news/ speech/2016/10/03/speech-by-world-bank-president-jim-yong-kim-the-world-bank-groups -mission-to-end-extreme-poverty (accessed on 22 June 2018).

2 Aside from India, Pakistan, Indonesia and the US, the remaining six countries are located in Africa: Nigeria, the Democratic Republic of Congo, Ethiopia, Tanzania, Uganda and Egypt. As of 2017, 6o per cent of the African population was under 24 years of age, and about four out of ten Africans was under 14 years of age. While population growth rates are expected to slow down by mid-century, Africa's population will continue to rise, from a forecast 1.7 billion in 2030 to an estimated 4.4 billion people by 2100 (UN 2017, 23). If the main challenge faced today in sub-Saharan Africa is the poor quality of employment, the prospect of massive unemployment looms on the horizon with an additional 12 million youths joining the workforce by 2020.

3 As will become apparent in the case of India's IT industry, the skill-biased technological change (sвтC) hypothesis suggesting a shift towards educated workers as a response to 
In India, for example, a survey of young people aged 16 to 25 found that $5^{2}$ per cent of those polled believed that AI machines or computer programmes would replace human jobs within a decade. ${ }^{4}$

Academic studies concerned with this shift to automated labour and impending robotised or computerised work, commonly glossed as the Fourth Industrial Revolution, tend to vary between the alarming prospect of a jobless future and the optimistic vision of a society free from taxing work. For some, the declining costs of automation and a move to capital-intensive technology will exacerbate the scope and impact of this transformation, with estimates ranging from 9 per cent of job 'automatibility' across OECD countries (Arntz et al., 2016) to 40 to 60 per cent of US jobs potentially lost within the next twenty years (Frey and Osborne, 2017; Hicks and Devaraj, 2015). ${ }^{5}$ For others, humans should embrace the freedom of a fully automated economy (Srnicek and Williams, 2015; Livingston, 2016) or devise new mechanisms to either slow down the effects of automation or compensate for lost income in the form of robot taxes (Guerreiro et al., 2017) or Basic Income programmes (Barchiesi, 2007; Davala et al., 2015; Standing, 2017; Seekings and Matisonn, 2010). Aside from an emergent critique in the digital studies literature concerned with relations of exploitation and marginalisation in the digital economy (Casilli, 2017; Fuchs, 2016; Graham et al., 2014), the exposure of the global South's workers to automation has been largely overlooked, as have the lessons it may offer with regard to addressing changing conceptions of production in an internetenabled and increasingly interconnected economy. Rather than reducing technological unemployment to the Schumpeterian 'gale of creative destruction' and the gloomy prospect of a Luddite fallacy, or embracing futuristic visions of an automated post-work scenario and the 'post-wage' realities of an ondemand 'gig economy', the fundamental question we seek to address hinges on the institutional division of labour and the social and political conditions enabling the adoption of technology: what working future awaits the next generation of workers? And if robots are replacing human labour, is a new social

technological change may no longer hold sway with the advent of increasingly autonomous machines capable of non-routine and cognitive tasks. See Goos et al. (2014) for a review of sвтс.

4 See the research presented on the website Infosys, Amplifying Human Potential: Education and Skills for the Fourth Industrial Revolution, http://www.experienceinfosys.com/ humanpotential (accessed on 21 June 2018).

5 Aside from the creation of new jobs fostered by technological change, this occupation-based approach to the potential for automation and computerisation may underestimate the need for tasks performed by humans. For an alternative tasks-based approach to computerisation, see Arntz et al. (2016). 
contract needed to compensate for the loss of taxable (human) income, rising income inequality, and the unprecedented power of large multinational corporations?

According to estimates of the International Labour Organization (ILO), irregular or underemployment-informal, casual, or temporary work-affects up to 75 per cent of the workforce, particularly in LMCs. By sheer demographic pressure and the prevalence of informal work, shored up by cheap access to robust data communication networks, workers in these countries are rapidly inching closer to experiencing the impact of automated or digitally enabled non-standard employment. ${ }^{6}$ Important as it may be to estimate what jobs will be available and to prepare workers accordingly, it may not be enough to tackle inadequate training in 'marketable' skills or create new entrepreneurship opportunities for those dispossessed of work. There are also considerable political consequences induced by the unfettered adoption of technological innovations in the world of labour. These would include added surveillance of and scrutiny over personal and working lives, from cashless transactions to remote desktop and keystroke monitoring, as well as the unregulated, corporate-owned troves of information amassed by data mining and predictive algorithms. While these are important issues, our main goal in this chapter is to examine the actual and potential exposure of temporary, contracted, and freelance work to computerisation and automation, on the one hand, and the opportunities and limitations afforded by access to digital labour platforms to mitigate, rather than exacerbate, the precarity prevalent in LMCs, on the other.

The remainder of this chapter assesses sector-specific trends and ongoing transformations in India's job market with a specific focus on the information technology (IT) industry. The IT industry and IT-enabled services in India face high labour costs, global competition, and the rapid adoption of technological advancements, making them particularly vulnerable to job loss and replacement. Moreover, most studies of automation have been largely confined to low-wage, low-skilled jobs, and the three decades of IT transformations in India offer an important case study through which to assess the adoption of technology in high-skilled industries. The chapter concludes by suggesting that a new international convention on digital labour is necessary to face the challenges of work and social protection in the twenty-first century. We now turn to an overview of India's job market.

6 The ILO (2016) defines non-standard employment (NSE) as work that falls outside the realm of standard employment, understood as a full-time, indefinite bilateral employment relationship. 
This section examines the challenge posed by a burgeoning working-age population with a decrease in agriculture and public sector jobs. India's modest job growth is exacerbated by technological advances and automation, and with a shift of stable employment away from manufacturing and construction to services, present and future generations are already experiencing the risks of heightened working precarity in the country.

\subsection{Jobless Growth in Manufacturing}

In the few decades since India's economic liberalisation and despite changes in the overall make-up of public and private sector employment, the fundamental structure of employment and self-employment in India has not been altered significantly (see Figure 11.1). ${ }^{7}$

\footnotetext{
$\%$ of total

population
}

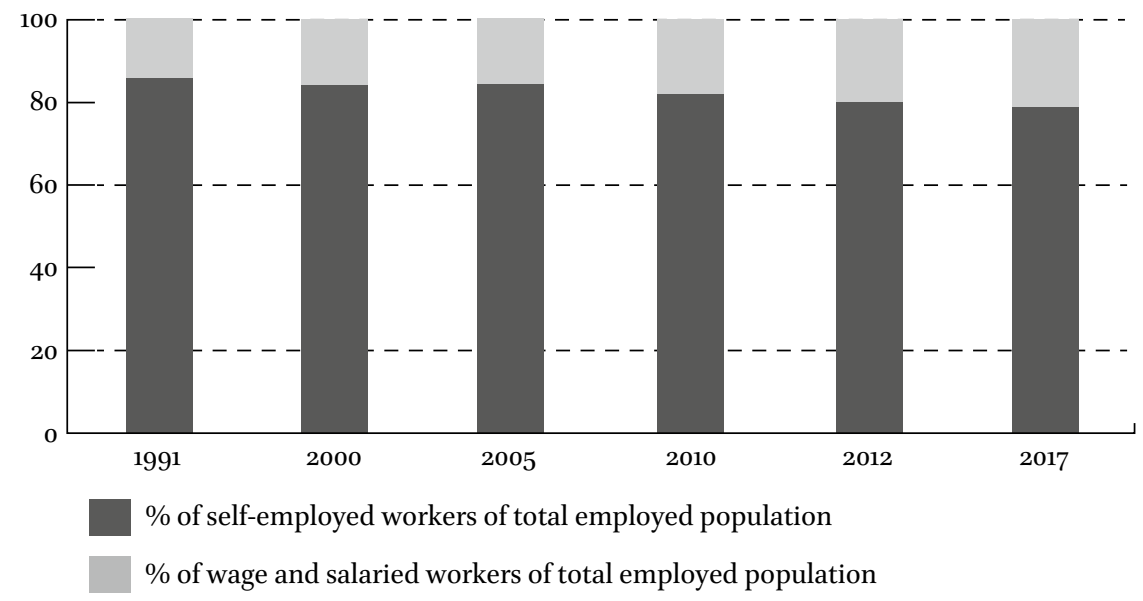

FIGURE 11.1 Self-employed workers and salaried workers in India SOURCE: WORLD BANK (NO DATE), WORLD DEVELOPMENT INDICATORS: INDIA.

7 Public sector employment decreased from 19.466 million jobs in 1995 to 17.548 million in 2011, with corresponding gains in private sector employment. Data from the Open Government Data Platform, India, https://data.gov.in/catalog/employment-public-sector-and-privatesector (accessed on 10 September 2018) and the Quarterly Reports on Employment Surveys, 2012-2017 (Government of India, 2017b). 
However, labour-shedding transformations and a move towards capitalintensive industries have largely offset post-199os employment gains. ${ }^{8}$ While the loss of public sector jobs represents a steady march towards less secure or stable jobs, only 17 per cent of the workforce earns a regular wage or salary, and almost half of the working population is either self-employed or casually employed. Between 2000 and 2017, rural worker numbers declined from 59.9 per cent to 44.2 per cent of the total workforce, with manufacturing, construction and service jobs compensating for losses in rural jobs (See Figure 11.2). ${ }^{9}$

Yet, India's economic growth has spurred only modest or 'sluggish' job creation -if any at all (Tejani, 2016). ${ }^{10}$ While the employment-to-population ratio for the population above 15 years of age has been steadily declining in India, the working-age population in the age group 15-64 years has risen (see Figure 11.3). ${ }^{11}$ Considering the expected increase in the working-age population over the next decade, this jobless growth may spell trouble for the future.

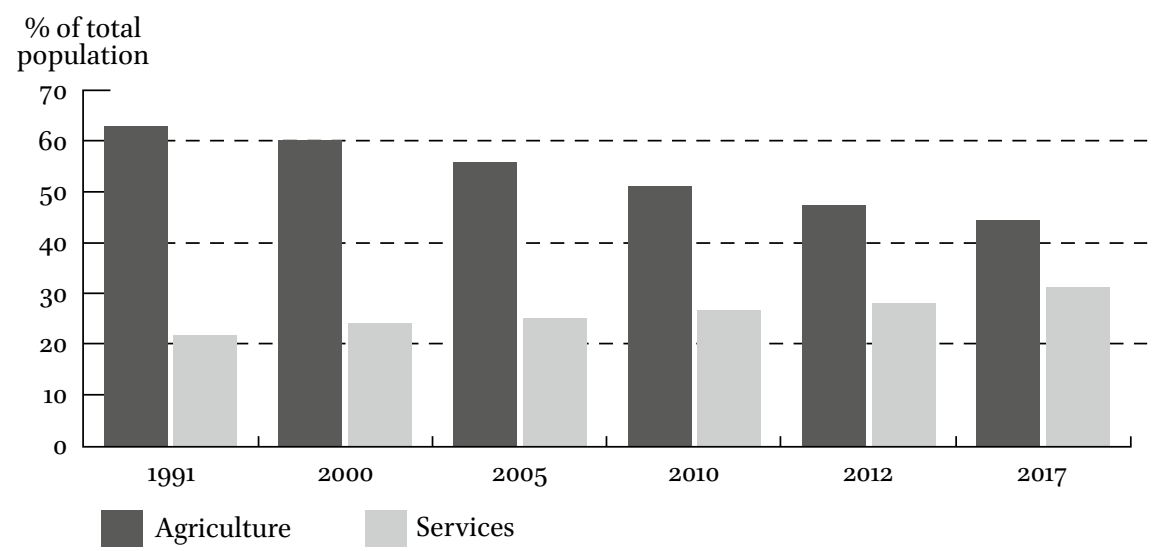

FIGURE 11.2 Indian population employed in agricultural and services sectors SOURCE: WORLD BANK (NO DATE), WORLD DEVELOPMENT INDICATORS: INDIA.

$8 \quad$ See Kannan and Raveendran (2009) for the manufacturing sector and Tejani (2016) for a broader account of increased productivity without labour-intensive production.

9 Service jobs increased (from 23.7 per cent in 1999-200o to 26.9 per cent in 2011-12) as did construction jobs (from 4.5 per cent to 10.6 per cent in 2011-12). Figures are from the National Sample Survey Office data, in Misra and Suresh (2014).

10 The Economic Survey published by India's Ministry of Finance acknowledges that 'employment growth has been sluggish' for the years preceding 2016-17 (Government of India, 2017, 61).

11 We use the employment-to-population ratio as a more accurate indicator of employment generated. Employment is defined as persons of working age who, during a reference period, were engaged in any activity to produce goods or provide services for pay or profit. 


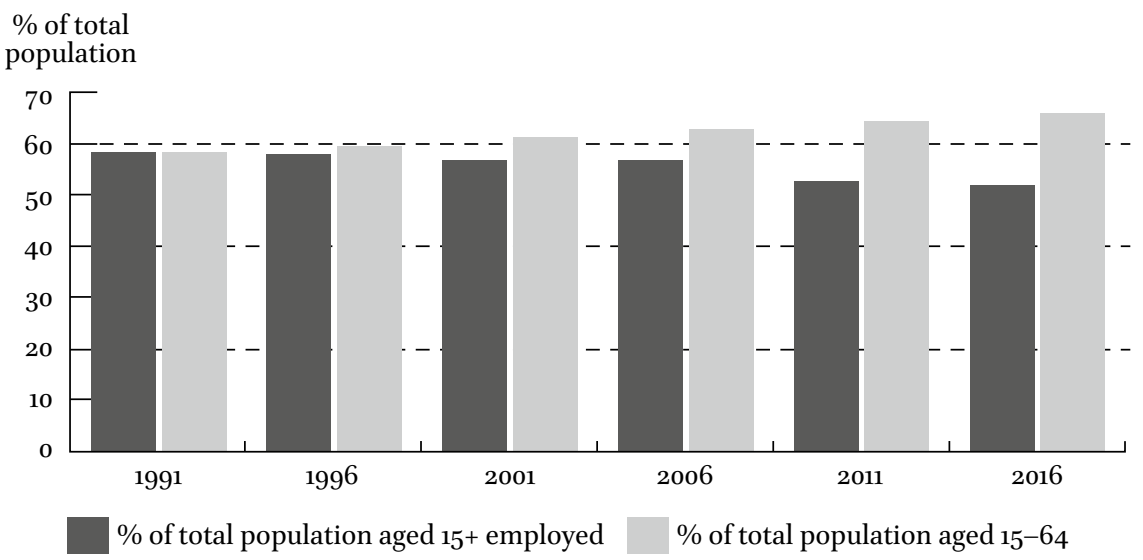

FIGURE 11.3 Employed working-age population and total working-age population in India SOURCE: WORLD BANK (NO DATE), WORLD DEVELOPMENT INDICATORS: INDIA.

In this context of jobless growth, the ILO observes that India's strong economic growth of 7.6 per cent $\left(2015^{-16}\right)$ has not translated into improved employment, but is rather accompanied by fewer jobs and rising inequalities. ${ }^{12}$ With the informalisation of the organised sector, a significant number of workers are without access to employment benefits and social security. ${ }^{13}$ Along with decreases in the overall employment rate, labour force participation in India's job market has declined steadily since the 199os. In official statistics, unemployment has remained at low levels of 4 to 5 per cent for 2017, which can be attributed to the sharp decline in labour force participation amongst women and to sampling bias. ${ }^{14}$ Finally, the distinction between temporary and permanent employees is increasingly blurred and is often identified as the primary cause of labour unrest in many industries, leading the government of India

12 India's GDP growth was 5.6 per cent for $2012-13,6.6$ per cent for $2013-14$ and 7.6 per cent for 2015-16. Per capita income also increased, from 5.8 per cent for 2014-15 to 6.2 per cent for 2015-16. Despite a declining poverty rate (from 37.2 per cent for 2004-05 to 21.9 per cent for 2011-12), inequality has risen particularly in urban India, where the Gini indexused as a measure of inequality—has increased from 34.3 for 1993-94 to 39.3 for 2009-10 (see ILO, 2018 and World Bank, 2018).

13 The organised sector consists of 'incorporated' or legally registered and regulated establishments consisting of ten or more workers. The ILO notes that the share of workers in the unorganised sector fell only marginally, from 86.3 per cent for $2004-05$ to 84.3 per cent for 2009-10 and to 82.2 per cent for 2011-12 (ILO, 2018).

14 For example, female labour force participation in rural areas dropped from 52.5 per cent for 2004-05 to 39.9 per cent for 2009-10, and in urban areas from 26 per cent to 21 per cent during the same period. India has the lowest labour force participation rates amongst women (ILO, 2018). 
to consider enforcing salary parity to mitigate differences between stable and short-term contracts. ${ }^{15}$

Manufacturing jobs are the most significant source of regular employment and until recent years contributed the lion's share of new jobs created in the private sector. ${ }^{16}$ Out of the 10 million new manufacturing jobs, the automobile industry accounted for the largest number (7.6 million), mostly in auto component manufacturing but also in auto sales, services, transportation and logistics, for a total of 25 million jobs in the automobile industry in $2016 .{ }^{17}$ This figure is poised to increase over the next few years, with an ambitious governmental Automotive Mission Plan (2016-26) estimating 65 million new direct and indirect jobs in the automobile industry (SIAM, no date). There is no detailed survey information on the impact of automation on jobs in the manufacturing sector, but frequent newspaper reports stress the snowballing adoption of robotic devices in manufacturing processes. ${ }^{18}$ More broadly, these estimates minimise the number of jobs needed to match the increase in the working-age population or the skills necessary to tackle technological unemployment. A careful assessment of sector-specific susceptibility to automation and trends in employment would seem to recommend a shift away from manufacturing-intensive sectors, to sectors less susceptible to automation, such as the education sector, which already accounts for 24.35 per cent of all service jobs.

15 The government of India has initiated changes in the Contract Labour (Regulation \& Abolition) Act of 1970. At the time of writing, the draft bill was announced and pending the consultative process. See the Ministry of Labour and Employment, 'Amendment in the Contract Labour (Regulation and Abolition) Act, 1970', available at https://labour.gov .in/sites/default/files/Amendment_Contract_Labour.pdf (accessed on 7 September 2018).

16 Notwithstanding the consistent growth in community, social and personal services (16.03 million in 1995 to 23.50 million in 2011) along with finance, real estate and insurance jobs (2.93 million in 1995 to 17.18 million in 2011). Open Government Data Platform, India, https://data.gov.in/catalog/employment-public-sector-and-private-sector (accessed on 10 September 2018).

17 Government of India (2011), 'Human resource and skill requirements in the auto and auto components sector', the Ministry of Skill Development and Entrepreneurship and National Skill Development Corporation. According to this report, an additional 2.7 million jobs are to be added to the existing 12.81 million jobs generated in the sector by 2022, largely in auto component manufacturing.

18 Automation is increasingly used by automobile companies such as Maruti Suzuki, with 5,000 robots in its plants in India. Ford's latest plant in Gujarat has more than 500 robots, most of which operate in the body shop area, whereas its older plant in Chennai has only 100 robots. 


\subsection{Retail Jobs and the Risk of Automation}

The retail sector in India, at first glance, offers a hopeful avenue for the majority of Indians having completed either primary or secondary school. ${ }^{19}$ With a large Internet user base, cash on delivery and electronic payment systems have become increasingly commonplace in India. However, the service sector has not generated as many jobs as expected due to high productivity and minimal labour input (Gordon and Gupta, 2004). In fact, despite a strong growth of online retailers and Internet penetration, in $2016 \mathrm{e}$-commerce and related services accounted for only about one million jobs in India. ${ }^{20}$ The biggest employers in the e-commerce business in India are Amazon and Flipkart, which have pushed to expand automated warehouses and fulfilment centres. ${ }^{21}$ Following a global trend, large online retailers such as Amazon have begun moving from e-commerce operations to online marketplaces for work in India. ${ }^{22}$

The bulk of employment opportunities in the sector are presently generated in automation-prone jobs in logistics, warehousing and delivery services. Conveying, organising and loading tasks are now increasingly performed by robots and though automation is presently limited, it is set to increase in warehousing and storage operations in the near future. For example, e-commerce market leaders (including Flipkart, Jabong, Myntra, and PepperFry) and logistics companies (Aramex, DTDC, Delhivery, and Gojavas) are serviced by GreyOrange, a multinational firm that designs, manufactures and deploys advanced robotics systems for automation at warehouses and distribution and fulfilment centres. GreyOrange has entered into an exclusive partnership with the Indian

19 Some estimates suggest that 12 million jobs will be created in e-commerce and related services by 2025 (Bhandari and Srinivas, 2016).

20 A 2016 joint KPMG and Snapdeal report suggested that e-commerce can create 1.45 million direct jobs by 2021, with one million of these jobs in logistics and warehousing. The online seller base is projected to grow to 1.3 million by 2020 with the creation of an additional 10 million new jobs. These expectations are based on estimates of market growth and of an increase in the numbers of online shoppers (KPMG and Snapdeal, 2016).

21 In 2017, Amazon reported a total of 50,000 people on its payrolls in India, making it the company's second largest workforce centre after the US. In 2016, Flipkart had a total of 30,000 employees, despite plans to lay off between 700 and 1,000.

22 Amazon's Mechanical Turk, a marketplace for the 'on-demand' workforce, is perhaps the most popular of these labour or 'crowd-work' platforms, despite recent restrictions with regard to international workers (De Stefano, 2016; Bergvall-Kåreborn and Howcroft, 2014; Irani, 2015). Although most of the direct jobs created by Amazon will be in fulfilment centres or in customer service, Amazon announced in early 2017 plans to create 5,000 remote customer service jobs. Increasingly, these positions are being framed as 'employee friendly' as they enable flexible work. One example of the latter strategy emerged in August 2017, when Amazon India launched a cost-efficient virtual customer service platform for skilled workers seeking to work from home. 
company Godrej \& Boyce Mfg. Co. to market and distribute in India its proprietary warehouse automation solutions, the Pick-Put-To-Light (PPTL) system, responding to the growing demand for entry-level warehouse automation solutions. The remaining one-third of jobs created by online retailers and service providers are in customer care, IT and top management, which require higher education, and less significantly in research and development, data analytics, AI and machine learning. ${ }^{23}$

Overall, the liberalisation years of the 1980 s and 1990s in India were met with contradictory calls for more stringent laws or further deregulation. Enterprises adopted a strategy of capital deepening-modernising, automating and substituting labour with capital (Ghose, 1994) —and resorted to contract labour, which increased from 12 per cent of total manufacturing work in 1990 to 23 per cent in 2002. This has been possible in part because of a state that appears to favour an agenda of decent and secure work, while enabling an environment that normalises contraventions. New strategies with regard to outsourcing have also negatively affected trade unions, with a concomitant loss of bargaining power with which to negotiate wages, allowances, benefits or social protection (Sharma, 2006). More broadly, the future of work critically hovers over the move towards e-commerce, online labour and service platforms in India, specifically in transportation, hospitality, and food services.

We now turn to a discussion of the specific challenges and opportunities posed by the emerging digital economy in India, from tech-work platforms to the IT sector.

Work today relies on an interconnected division of computerised and human labour, with on-demand workers for hire in platform services, outsourced customer support or human resources, and automated processes to facilitate payroll and accountancy. With increased and increasingly inexpensive mobile internet access, app-based service platforms ensure easy coordination and a seamless customer experience, inasmuch as they allow workers to overcome the geographic constraints of local labour markets. This section examines digitally mediated work in India to understand the challenges of a digital labour

23 In August 2017, as widely reported in the media, Amazon announced plans to hire 1,000 workers in India, including research scientists and data analysts as well as natural language processing, artificial intelligence, machine learning, and Android developers. See, for example, Anand, J. and Shilpa Phadnis (2017). 
marketplace. Despite the possibilities for labour arbitrage in global platforms, studies have shown that there is an imbalance in data and value transfer, skewed towards the global North (Casilli, 2017) in relations of digital production that rest upon a 'vast and complex network of interconnected, global processes of exploitation' (Fuchs, 2016, 21). Workers in the global South are more prone to economic exclusion, sub-contracting, and loss of bargaining power, and contrary to the idea that a worker's location is rendered irrelevant, it is the imbalanced nature of relations between places that foster the development of these digital work networks (Graham et al., 2017, 142).

\subsection{Freedom and Flexibility, On-demand}

For the first generation of software developers and digital workers, coding and software programming rested upon free use, at once open source and shared with no restrictions (Coleman, 2013). The crowd-sourced nature of the 'sharing economy' (Sundararajan, 2016) is frequently portrayed as a communitybased, liberating experience unbound by the shackles of formal employment. For work platforms specifically, a vision of freedom is espoused in the figure of the freelancer: the worker is free to work without constraints, though also free from regulation and protection. For a growing number of critics, sharing labour platforms (on-demand and micro-work platforms) are unregulated, profit-seeking, data-generating infrastructures that rest upon opaque labour supply chains and asymmetrical algorithmic operations (Shapiro, 2017; Graham et al., 2017; Rosenblat and Stark, 2016). Be it under the guise of computation services (Irani, 2015) or short-term, task-oriented work, on-demand work is 'labour without overhead' (Shapiro, 2017, 14).

With dwindling employment opportunities, a large number of Indians are turning to temporary employment or tech-enabled freelance work. India has an estimated 2.1 million temporary workers in the organised sector and hosts the third largest flexible staffing workforce in the world after China and the United States. India has also become the largest supplier of digital labour, providing data-processing work, software and technology services (Kässi, O., M. Hadley, and V. Lehdonvirta, 2018). ${ }^{24}$ In the absence of stable work, online piecework has become a prominent means of securing a livelihood. Corporations also increasingly favour and enable unprotected, freelance work, moving

24 In the online labour platform Truelancer, which offers freelancers for hire, India has the largest workforce contingent after the US, with about 15 million users (Jesee, 2015). A survey by Payoneer, a payment platform for freelancing, reveals that 78 per cent of these workers are men, and about half earn an hourly rate of USD 10 or less on average (Strok, 2015). 
towards project-based work and short- or medium-term employment. ${ }^{25}$ Without enough jobs to go around and leaner technology firms, this 'gig economy' is expected to become more widespread in the future in what we could call a 'global digital factory'. Unlike the 'global factory' of the 1990s and dawn of the new millennium's sweatshops and maquiladoras (Fuentes and Ehrenreich, 1983; Louie, 2001), these online marketplaces and the new kind of labour therein performed are not spatially bound but represent instead an infrastructure of digital labour (Scholz, 2013). A common example would be Amazon's Mechanical Turk, which allows recruiters to 'tinker' with human workers by allowing 'employers to experiment with the uses of human labour, exploring new business areas with little accountability or obligation to those employed in the experiments' (Irani, 2015, 230).

The emergence of this disposable and flexible workforce is not a new phenomenon in India. At least since the 1990s, Indian-run recruitment agencies ('body shops') have supplied skilled Indian IT professionals for foreign companies and institutions' temporary, on-site projects, without incurring the financial burden of layoffs for the destination country. These body shop operators and agencies would recruit and make available a highly mobile and flexible labour pool, effectively selling workers abroad while selling jobs to Indian workers (Xiang, 2007). With growing visa restrictions and the possibility of delivering IT services off-site, the need for international body shopping slowed down in the mid-20oos. Hyderabad, the capital of the State of Telangana in Southern India, was formerly a 'capital node in global body-shopping networks' (Xiang, 2007, 48). Today, it rivals Bengaluru for the title of IT hub of India. During visits to these technological hubs, news that jobs were to be outsourced or rendered redundant was received with uneasy silence by IT workers who were reluctant to discuss this newfound predicament on the record. The reported rise in tech workers' suicides, however, was a sombre reminder of the current job crisis. ${ }^{26}$ In informal conversations held with IT and software developers employed by US multinational corporations in both Hyderabad and Bengaluru, there was noticeable apprehension regarding the prospect of redundancy. As described to the authors by an Amazon employee in Hyderabad, there is a sense that the

\footnotetext{
25 For example, PwC and Ernst and Young organise online marketplaces and labour pools from which to tap freelancers for internal projects and occasional hires. For smaller companies, core work is increasingly allocated to freelancers online.

26 As massive layoffs were taking place in technology companies in India, in July 2017, the suicides of two technology workers were reported in newspapers in Bengaluru and Pune. Based on notes left by these workers, their deaths were attributed to the lack of job security in the tech industry (See Shinde, 2017).
} 
current workforce is paving the way for a future of automated processes and diminished employment.

\subsection{Autonomy and Control}

Given the prevalence of on-demand transportation services, research on Uber and other ride-sharing tech platforms has demonstrated information asymmetries generated by algorithmic operations (Rosenblat and Stark, 2016) and the importance of reputational capital among workers largely devoid of any other form of protection. Though responsible for their own equipment, workers depend on the technological brokerage of these platforms to access the labour market (Surie and Koduganti, 2016; Shapiro, 2017). These companies' push for disintermediation carries two important consequences for the current analysis: first, employment is defined as an autonomous monetisation of the self, contingent upon a certain threshold of acceptance or reputation; second, the worker's apparent freedom is undermined by the control and surveillance exerted by these companies.

Ethnographic studies of Uber and $\mathrm{Ola}^{27}$ drivers in India have shown how workers value the freedom from the obligations inherent in conventional employment and the flexibility that comes from deciding for how long, when, and where to work (Surie, 2017). Working for Uber or Ola can be equally liberating for the worker in terms of caste and communal identities, and a sense of autonomy is reinforced by the perception of rising incomes and the social mobility that comes from an entrepreneurial profession. Yet this rhetoric of autonomy plays into the hands of the technology companies operating sharing platforms. In early 2017, Uber and Ola drivers noticed a dip in their earnings. After amassing a large number of drivers, most of whom accessed bank credit to pay off their car loans, the companies brought down their fares and incentives resulting in a 60 per cent drop in incomes and in 24 per cent of the drivers renouncing these platforms a month after the changes (Business Standard, 2017). Initially lured by the promise of autonomy and higher incomes, the reported 250,000 Uber drivers and 350,000 Ola drivers are not legally considered employees of these technology companies, and the drivers' grievances are not dealt with by the state labour department. Notwithstanding this predicament of autonomy, Uber conducts interviews and recruits drivers, and exerts mechanisms of control through complaint mechanisms and rating systems with impacts on remuneration, giving credence to an actual employment relationship.

27 Ola is an Indian online transportation network company. See Ola's website https://www .olacabs.com (accessed on 18 August 2018). 
The inability to decide fares or incentives or the broader terms of the working relationship between worker and employer raises significant questions about the nature of such employment and its future. This condition of work is not just a fragile and insecure experience; it is one that is wrapped in invasive control mechanisms. ${ }^{28}$ Drivers earning less than the minimum wage have their every move subjected to technologically enabled forms of surveillance as they grant an inordinate level of access to personal information (location, driving routes, and acceptance rate) in order to power the algorithmic operations of the platform. They are not unlike factory workers under constant surveillance and supervision, albeit without regular wages and health or social security benefits.

\subsection{India's IT Industry}

India's IT and software industry accounts for an estimated 3 million jobs (Upadhya, 2016, 2). Along with business process outsourcing (ВРО) jobs for third-party providers, a growing share of new jobs created each year in India are generated by the IT sector (see Figure 11.4). In 2017, however, the sector underwent its first jobs crisis since 2008. If the sector is often hailed as representing the future of work in India, the number of jobs for IT workers and programmers in Bengaluru and Hyderabad is diminishing, with 56,00o employees slated to be laid off in 2017 according to widespread media reports (see for example Siddiqui and Sharma, 2017). This doubles the number laid off in 2016 and represents the largest retrenchment in the technology sector thus far.

If the IT work of the late 199os and the start of the new millennium entailed labour-intensive and fragmented tasks that resulted in the deskilling of its workers (Upadhya and Vasavi, 2008), the tech world now embraces a trimmed down, highly skilled workforce that can creatively develop whole products. Foreign companies that relied on body shops have reduced their workforces in India and look towards future technology developments in cloud computing, AI and machine learning technologies, with Google and other tech giants buying up small Indian start-ups working with AI and deep learning systems. For the first time in India, companies are returning to the United States for political, economic and technological reasons. Infosys, one of the earliest and largest technology companies in the country, has announced its plans to hire

28 First denounced by The New York Times (see Isaac, 2017). Uber's use of the 'greyball' tool to gather detailed personal and work-related information on its drivers and evade the control of authorities is one example of deploying surveillance technologies through software applications. 


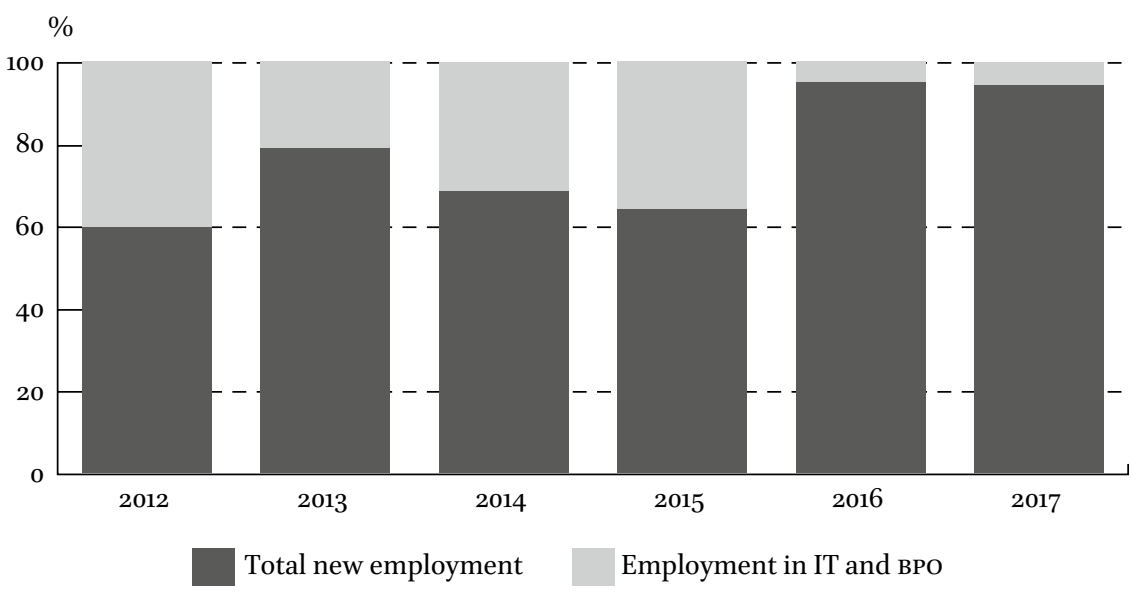

FIGURE 11.4 New Employment and Employment in IT and в во in India SOURCE: GOVERNMENT OF INDIA (2017b), QUARTERLY REPORTS ON EMPLOYMENT SURVEYS, 2012-2017.

Note: Between 2009 and 2015, the Quarterly Employment Survey data was sourced from 2,000-3,000 establishments. In 2016, the survey was revamped to include more than 10,000 establishments, which accounts for the significant correction in employment numbers for that year and the year that follows.

more American workers at an estimated loss of four trained Indian positions for each new US-based job, with other companies following suit. Whether this move should be attributed to the improving skills of American graduates, the rising wages of Indian programmers, a corporate realignment towards the US-based customer base for political expediency, or a combination of these factors, such analyses disregard the fact that automation already accounts for much of the routine coding, testing jobs, and mining of call centre data (Pallotta and Delmonte, 2013).

The realities of IT-enabled industries or the global outsourcing of flexible workers have been documented ethnographically (Amrute, 2016; Ho, 2009; Lane, 2011; Patel, 2010; Upadhya, 2016) but the recent talk of outsourcing and dismissals stunned our interlocutors in the IT industry and threw into question the promises of social mobility personified by its nouveau riche middle class of IT professionals (Fuller and Narasimhan, 2007). In fact, many routine programming jobs are becoming defunct as automation increases efficiency and enhances productivity, scrapping a few additional workers from the payrolls. More broadly, these developments bespeak the first effects of AI-led software production: first, when $\mathrm{AI}$ is largely enabling and preparing the manufacturing 
process of the future through autonomous decision-making, algorithm learning, and software coding, humans are seemingly left with being the creative complement to AI or responsible for carving out exceptions in automated processes. Second, as this surplus of high-skilled labour in the Indian IT sector enters global labour markets, the responsibility of ensuring the necessary means of production shifts onto the workers themselves.

In the experiences of flexibility and autonomy examined here and with the distinction between formal and informal, standard and non-standard becoming increasingly thin, it is not surprising that demands for job security have been replaced by demands for income security (Sharma, 2006). Presented as the magic bullet that will remedy the lack of jobs, Basic Income initiatives and new redistributive policies should be part of the ILO's agenda to reinforce initiatives geared towards decent work and social protection, much like the call for 'serious consideration' to be given to Universal Basic Income programmes in India's Economic Survey of 2017. ${ }^{29}$ Beyond redistributive policies, however, the ILO should be able to respond to the challenges of automation and the effects of a growing workforce of digital workers accessing the labour market through global platforms.

The ILO has sparked a discussion about the impact of automation on the global division of labour by binding its centennial initiative to the future of work. The ILO is not a stranger to the pitfalls and analytic limitations of thinking about the future of work through the prism of decent or standard employment, and has made important strides in assessing work in gig economies (De Stefano, 2016) and non-standard contract work in India (Srivastava, 2015). However, in these and other fora, work is often reduced to an antithetical condition of freedom and dependence, joblessness or actively choosing not to work (Denning, 2010; Calvão, 2016). In every other respect, the ILO has been reluctant to address the paradigm of post-wage or post-human labour. This is not to say that humans will ultimately be deemed redundant, or that all jobs will vanish. Rather, we propose that the shared global yearning for autonomy

29 Universal Basic Income is being considered as a policy to address issues of weakly implemented welfare schemes with misallocation, leakages and exclusion of the poor. The objective is not to substitute for state capacity or replace existing welfare provisions and access to public goods but to ensure that welfare transfers are more efficient and to supplement work income (Government of India, 2017a). 
and flexibility signals an aspiration for meaningful dependency as a mode of productive action, which is to say the capacity to create and maintain relations of interdependence (Ferguson, 2015; Graeber, 2001). Seen as labouring activity, the digital work of the future will necessarily entail meaningful human action. But if a measure of success for technology companies entails the concealment of the human element behind automated data-processing and digitally enabled work (Irani, 2015), how can the ILO valorise digital work in-between dehumanising experiences and the desire for human autonomy and flexibility?

First, the ILO holds a particular responsibility in addressing the need to valorise workers across labour platforms, including the added burden that accrues from owning the resources needed for production. Internationally, companies such as Airbnb and Uber have come under increasing legal scrutiny for corporate practices that drive down wages, shift risk to their workers, or evade social and fiscal responsibilities. In the United States, Uber was forced to settle two separate class action suits, but has retained the ability to run an operation of 'independent contractors. ${ }^{30}$ A London court, on the other hand, recently rejected Uber's argument of providing a common 'platform' of partners, in a decision with far-reaching implications. ${ }^{31}$ This move towards virtual human clouds, digital products and flexible contractors should be recognised by a convention on digital work that addresses the social value of work and the diminished role of human labour in economic productivity, and how to best ensure ILO standards and protections for those embracing piecemeal work in this new, global digital factory. As proposed here, this means taking seriously the freedom ascribed to these jobs by many workers while scrutinising the unregulated data-gathering power and control exerted by large corporations.

Second, we suggest, the ILO should further engage with forms of digitally mediated work and network governance, and develop a new understanding

30 The California Labor Commission ruled in favour of considering Uber drivers as company employees in 2015 , but only in regard to one individual worker. Similar legal and political challenges to Uber and other corporations that emerged on the heels of the sharing economy have cropped up. Uber's driverless pilot project in Pittsburgh was shut down in 2017 by city orders. In addition, Airbnb's operations have been restricted in different countries due to the impact of its commercial operations on local residents.

31 The London tribunal held that drivers were in fact company employees, and thus were entitled to a living wage and holiday pay as per the country's labour laws. However, the ruling remarked that the only route for promotion meant spending more hours at the wheel, and that drivers were unable to determine business terms including the right to negotiate, except to agree to a lower fare than that set by Uber. It further observed that Uber amends contracts unilaterally. As of September 2017, Uber has been stripped of its commercial licence in London while the decision is under appeal. See Mr. Y. Aslan \& Others vs. Uber B.V. and Others, case no: 2202550/2015. 
of digitised labour relations no longer tied to conventional working arrangements but to ways of monetising the self in a digital ecosystem. Beyond the terms of employment or independent contract work, a modicum of workers' control and autonomy over digital labour platforms should further include ownership or transferability of ratings and reputational capital (De Stefano, 2016, 22). This brave new world of the sharing economy, specifically that mediated by autonomous work facilitated by technology platforms, signals the need for policy and legislation to regulate such working environments and the forms of digital surveillance and control exerted by private companies. In reimagining work, however, it is important not to rush any policy decisions in that the flexible workforce characteristic of digital economies shares a number of features with standard employment and assumes an integral role in the functioning of global supply chains (Tsing, 2009; De Stefano, 2016). Given the lack of social protection in these sectors, more rigorous tax mechanisms and social protection benefits should be devised for contract, self-employed and temporary workers.

Third, attention to the new ecosystem of digital work opens up an important reflection on the digital commons and platform 'cooperativism' (Scholz and Schneider, 2016). If efforts to promote fair cooperatives and collective bargaining have been far more successful and widespread in countries such as India, this experience could conceivably be replicated across the automated and on-demand economy. ${ }^{32}$ As more and more seek the autonomy of working in these platforms, this effort should not be aimed at facilitating or curtailing the adoption of automated labour; rather, it should consider what it means to rely on privately owned technology platforms to access the labour market, the nature of providing services to multiple employers under the guise of recruiters and commissioners, and what constitutes the work product of digitally mediated, semi-automated labour. A push towards the collective co-ownership of digital platforms would be an important step in that direction.

Finally, by the same token, the ILO should consider in concert with national governments the effect of technological transfers to developing economies as well as the exposure of developed economies to a competitive and abundant global workforce in a new international division of labour. Concretely, this means devising national strategies to compensate for the unequal economic geographies of global digital work networks (Graham et al., 2014). In India, studies that highlight the risk of a jobless future have largely fallen on deaf

32 The Self Employed Women's Association is a noteworthy example of strengthened bargaining power through associative action in India (Rose, 1992; Agarwal, 1997). 
ears. Instead of adequately preparing for a loss of jobs to automation in India, technological advances and rising productivity have not been factored in when designing recent policy. Despite signs of expanding automation and growing job losses, India is intent on generating low-skilled contract work in the manufacturing sector (Srivastava, 2015). The recently adopted 'Make in India' policy, which focuses primarily on industrial production, is proof of this continued commitment to manufacturing, ignoring the new technologies that are replacing human labour. In this regard, future strategies by the ILO should be attentive to the dynamics of 'cunning states' that selectively implement certain neo-liberal policies and that 'capitalize on their perceived weakness in order to render themselves unaccountable both to their citizens and to international institutions' (Randeria, 2003, 1). This holds true of India's alignment of its latest five-year plan for job creation with the ILo's decent work programme. Moreover, the purview of laws ensuring basic working conditions or the safety and health of workers concerns the formal sector alone and should be expanded to include work falling outside the realm of 'standard employment' as a bilateral employment relationship. ${ }^{33}$

\section{$5 \quad$ Conclusion}

Historically, the ILO has been instrumental in enforcing international standards for the protection of labour rights. Despite the challenges of organising labour in the digital economy, this long-standing mission should ensure that future work will be realised as a social, meaningful activity and to its full potential with regard to equality and justice. Workers and small employers play a pivotal role in moderating corporate-fostered competition for lower pay and in fostering more transparent and ethical working arrangements. However, the new global technological brokers of piecemeal digital work should not be able to unilaterally set the rules of engagement between worker and customer, or single-handedly determine the relationship between employer and employee. In the absence of conventional jobs or standard employment, the terms of

33 See Lerche (2012). In a survey of factories employing more than one thousand workers, only 20 per cent were shown to pay minimum wage (Sharma, 2006), and adherence to a minimum wage is rarely followed in government-sponsored programmes. The national rural employment scheme launched to tackle unemployment in rural areas, for example, provides a minimum wage of INR 100 per day, or a fraction of the pay for comparable work determined by each state in India (Sankaran, 2011). 
access, use, and transaction in tech-enabled digital and virtual work should be placed squarely under democratic control.

This is not to suggest a return to the shared authority and autonomy of collective guilds, although there are lessons to retain from practices of shared control over production and equality among members as those emanating from the Social and Solidarity Economy (SSE). The United Nations Inter-Agency Task Force on Social and Solidarity Economy (TFSSE, 2014) defines these practices as pursuing some combination of economic, social, environmental and emancipatory objectives that include job creation, access to markets, provision of financial intermediation, and economies of scale. Based on principles of mutuality, solidarity and reciprocity, sse practices would enable better social protection and hold the potential to tackle vulnerable employment by bridging the transition from the informal to the formal economy. In a context of expanding digital precariousness, the ILO should openly advocate for the collective organisation of freelance platform work and the use of publicly owned, open software to mediate transactions between clients and service providers. This would encourage, in turn, an investment in human capital in a new commons of the digital economy.

\section{References}

Agarwal, B. (1997) "Bargaining" and gender relations: Within and beyond the household', Feminist Economics, 3(1), pp. 1-51, DOI: 10.1080/135457097338799.

Amrute, S. (2016) Encoding race, encoding class: Indian IT workers in Berlin (Durham: Duke University Press).

Anand, J. and Shilpa Phadnis (2017) 'Amazon to Hire Over 1,00o in India in a Big R\&D Push', Economic Times, 10 August, http://tech.economictimes.indiatimes.com/ news/internet/amazon-to-hire-over-10oo-in-india-in-a-big-rd-push/59997848 (accessed on 26 August 2017).

Arntz, M., T. Gregory and U.Zierahn (2016) The Risk of Automation forJobs in OECD Countries: A Comparative Analysis, OECD Social, Employment and Migration Working Papers No. 189 (Paris: OECD Publishing), https://www.oecd-ilibrary.org/docserver/ 5jlzgh56dvq7-en.pdf?expires $=1536583338 \&$ id $=$ id \&accname $=$ guest $\&$ checksum $=$ ${ }_{771} \mathrm{~F}_{7} \mathrm{~F}_{7} \mathrm{~F}_{752933} \mathrm{D}_{54} \mathrm{E}_{5} \mathrm{AgD}_{70} \mathrm{~B}_{3} 60678$ (accessed on 10 September 2018).

Barchiesi, F. (2007) 'South African Debates on the Basic Income Grant: Wage Labour and the Post-Apartheid Social Policy', Journal of Southern African Studies, 33(3), pp. 561-575, DOI: 10.1080/03057070701475575.

Bergvall-Kåreborn, B. and D. Howcroft (2014) 'Amazon Mechanical Turk and the Commodification of Labour. New Technology', Work \& Employment, 29(3), pp. 213-223, DOI: $10.1111 /$ ntwe.12038. 
Bhandari, P. and P. Srinivas (2016) India: More jobs per click: The employment potential of e-commerce, Economics India, HSBC Global Research report, July (Hong Kong: HSBC Global Research).

Business Standard (2017), 'Ola, Uber face Supply Squeeze: 24 per cent Drivers Leave as Incentives Drop', 19 June, http://www.business-standard.com/article/ companies/ola-uber-supply-drops-by-25-as-drivers-leave-due-to-lack-of-incentives117061900635_1.html (accessed on 21 February 2018).

Calvão, F. (2016) 'Unfree Labor', Annual Review of Anthropology, 45, pp. 451-467, DOI: 10.1146/annurev-anthro-102215-100307.

Casilli, A. (2017) 'Digital Labor Studies Go Global: Toward a Digital Decolonial Turn', International Journal of Communication, 11, pp. 3934-3954.

Coleman, G. (2013) Coding Freedom. The Ethics and Aesthetics of Hacking (Princeton and Oxford: Princeton University Press).

Davala, S., R. Jhabvala, S. Mehta and G. Standing (2015) Basic Income. A Transformative Policy for India (London: Bloomsbury Academic).

De Stefano, V. (2016) 'The Rise of the Just-in-Time Workforce: On-Demand Work, Crowdwork and Labour Protection in the Gig Economy', Comparative Labor Law and Policy Journal, 37(3), pp. 461-471.

Denning, M. (2010) 'Wageless Life', New Left Review, 66, pp. 79-97, https://newleftreview .org/II/66/michael-denning-wageless-life (accessed on 14 December 2018).

Ferguson, J. (2015) Give a Man a Fish: Reflections on the New Politics of Distribution (Durham and London: Duke University Press).

Frey, C.B. and M.A. Osborne (2017) 'The Future of Employment: How Susceptible are Jobs to Computerisation?', Technological Forecasting and Social Change, 114, pp. 254-280, DOI: 10.1016/j.techfore.2016.08.019.

Fuchs, C. (2016) 'Digital Labor and Imperialism', Monthly Review, 67(8), pp. 14-24.

Fuentes, A. and B. Ehrenreich (1983) Women in the Global Factory (New York City: South End Press).

Fuller, C.J. and H. Narasimhan (2007) 'Information Technology Professionals and the New-Rich Middle Class in Chennai (Madras)', Modern Asian Studies, 41(1), pp. 121150, DOI: 10.1017/Soo26749X05002325.

Ghose, A. (1994) 'Employment in Organised Manufacturing in India', Indian Journal of Labour Economics, 37(2), pp. 141-162, https://www.jstor.org/stable/29794268.

Goos, M., A. Manning and A. Salomons (2014) 'Explaining Job Polarization: RoutineBiased Technological Change and Offshoring, The American Economic Review, 104(8), pp. 2509-2526, DOI:10.1257/aer.104.8.2509.

Gordon, J. and P. Gupta (2004) Understanding India's Services Revolution, IMF Working Paper WP/04/171 (Washington D.C.: IMF), https://www.imf.org/external/pubs/ft/ wp/2004/wp04171.pdf (accessed on 17 September 2018). 
Government of India (2017a) Economic Survey 2016-17, (New Delhi: Ministry of Finance, Department of Economic Affairs, Economic Division), https://www.indiabudget .gov.in/es2016-17/echapter.pdf (accessed on 27 August 2018).

Government of India (2017b) Quarterly Reports on Employment Surveys, 2012-2017 (New Delhi: Ministry of Labour and Employment, Labour Bureau), http://labourbureau. nic.in (accessed on 17 September 2018).

Government of India (2011) Human resource and skill requirements in the auto and auto components sector (New Delhi:Ministry of Skill Development and Entrepreneurship and National Skill Development Corporation, Corporate Partner - KPMG) http:// www.voced.edu.au/content/ngv\%3A78369 (accessed on 20 August 2018).

Graeber, D. (2001) Toward an Anthropological Theory of Value (New York and Basingstoke: Palgrave), DOI: 10.1057/978-0-312-29906-4.

Graham, M., I. Hjorth and V. Lehdonvirta (2017) 'Digital Labour and Development: Impacts of Global Digital Labour Platforms and the Gig Economy on Worker Livelihoods', Transfer: European Review of Labour and Research, 23(2), pp. 135-162, DOI: 10.1177/1024258916687250.

Graham, M., B. Hogan, R.K. Straumann and A. Medhat (2014) 'Uneven geographies of user-generated information: Patterns of increasing informational poverty', Annals of the Association of American Geographers, 104(4), pp. 746-764, DOI: 10.1080/00045608.2014.910087.

Guerreiro, J., S. Rebelo and P. Teles (2017) Should Robots Be Taxed?, National Bureau of Economic Research, Working paper No. 23806, (Cambridge M.A.: NBER), DOI: $10.3386 /$ w23806.

Hicks, M.J. and S. Devaraj (2015) The Myth and the Reality of Manufacturing in America, Center for Business and Economic Research (Muncie: Ball State University), https:// conexus.cberdata.org/files/MfgReality.pdf (accessed on 10 September 2018).

Ho, K. (2009) Liquidated. An Ethnography of Wall Street (Durham and London: Duke University Press).

ILO (International Labour Organization) (2018) Decent Work Country Programme for India, 2013-2017 (New Delhi: ILO DWT for South Asia and Country Office for India), https://www.ilo.org/newdelhi/country/WCMS_232655/lang--en/index.htm (accessed on 15 June 2018).

ILO (2017) Global Employment Trends for Youth 2017. Paths to a better working future (Geneva: ILO), https://www.ilo.org/global/publications/books/globalemployment-trends/WCMS_598669/lang--en/index.htm (accessed on 10 September 2018).

ILO (2016) Non-Standard Employment Around the World: Understanding challenges, shaping prospects (Geneva: ILO), https://www.ilo.org/global/publications/books/ WCMS_534326/lang--en/index.htm (accessed on 17 September 2018). 
Irani, L. (2015) 'Difference and Dependence among Digital Workers: The Case of Amazon Mechanical Turk', South Atlantic Quarterly, 114(1), pp. 225-234, DOI: 10.1215/00382876-2831665.

Isaac, M. (2017) 'How Uber Deceives the Authorities Worldwide', The New York Times, 3 March, https://www.nytimes.com/2017/03/03/technology/uber-greyball-program -evade-authorities.html (accessed on 14 December 2018).

Jesee, R. (2015) 'Comparing Freelance Economies: India and the USA', Truelancer Blog, https://www.truelancer.com/blog/india-and-usa-comparing-freelance-economies2/ (accessed on 14 December 2018).

Kannan, K.P. and G. Raveendran (2009) 'Growth sans Employment: A quarter century of jobless growth in India's organised manufacturing', Economic and Political Weekly, 4(10), pp. 80-91.

Kässi, O., M. Hadley, and V. Lehdonvirta (2018) Online Labour Index: Measuring the Online Gig Economy for Policy and Research, (Oxford: Oxford Internet Institute, University of Oxford), http://ilabour.oii.ox.ac.uk/where-are-online-workers-located-the -international-division-of-digital-gig-work/ (accessed on 14 December 2018), DOI: 10.6o84/mg.figshare.3761562.v958.

KPMG and Snapdeal (2016) Impact of E-commerce on Employment in India (New Delhi: KPMG and Snapdeal), https:/assets.kpmg.com/content/dam/kpmg/in/ pdf/2016/12/impact-of-ecommerce-on-employment-in-india.pdf (accessed 21 February 2018$)$.

Lane, C. (2011) A Company of One: Insecurity, Independence, and the New World of WhiteCollar Unemployment (New York: Cornell University Press).

Lerche, J. (2012) 'Labour regulations and labour standards in India: Decent work?', Global Labour Journal, 3(1), pp. 16-39, DOI: 10.15173/glj.v3i1.1111.

Livingston, J. (2016) No More Work. Why Full Employment is a Bad Idea (Chapel Hill, N.C.: The University of North Carolina Press).

Louie, M. (2001) Sweatshop Warriors: Immigrant Women Workers Take on the Global Factory (New York City: South End Press).

Misra, S. and A.K. Suresh (2014) Estimating Employment Elasticity of Growth for the Indian Economy, Reserve Bank of India Working Paper Series No. 6, (New Delhi: Reserve Bank of India) http://rbi.org.in/scripts/PublicationsView.aspx?id=15763 (accessed on 6 June 2017).

Pallotta, V. and R. Delmonte (2013) 'Interaction Mining: The New Frontier of Customer Interaction Analytics', in C. Lai, G. Semeraro and E. Vargiu (eds.) New Challenges in Distributed Information Filtering and Retrieval. Studies in Computational Intelligence, 439 (Berlin and Heidelberg: Springer), DOI: 10.1007/978-3-642-31546-6_6.

Patel, R. (2010) Working the Night Shift: Women in India's Call Center Industry (Redwood City, California: Stanford University Press). 
Randeria, S. (2003) 'Cunning States and Unaccountable International Institutions: Legal Plurality, Social Movements and Rights of Local Communities to Common Property Resources', European Journal of Sociology/Archives Européennes de Sociologie, 44(1), pp. 27-6o, DOI: 10.1017/Sooo3975603001188.

Rose, K. (1992) Where Women are Leaders: The SEWA Movement in India (London: Zed Books and New Delhi: Vistaar Publications).

Rosenblat, A. and L. Stark (2016) 'Algorithmic Labor and Information Asymmetries: a Case Study of Uber's Drivers', International Journal of Communication, 10, pp. $375^{8-3784 .}$

Sankaran, K. (2011) 'Fundamental Principles and Rights at Work: India and the ILO', Economic and Political Weekly, 46(10), pp. 68-74.

Scholz, T. (ed.) (2013) Digital Labor: The Internet as Playground and Factory (New York and Abingdon-on-Thames: Routledge).

Scholz, T. and N. Schneider (eds.) (2016) Ours to Hack and to Own: The Rise of Platform Cooperativism, a new Vision for the Future of Work, and a Fairer Internet (New York and London: OR Books).

Seekings, J. and H. Matisonn (2010) The Continuing Politics of Basic Income in South Africa, Centre for Social Science Research Working Paper No. 286 (Cape Town: CSSR), https://open.uct.ac.za/handle/11427/19173 (accessed on 10 September 2018).

Shapiro, A. (2017) 'Between autonomy and control: Strategies of arbitrage in the "on-demand" economy', New Media \& Society, 20(8), pp. 2954-2971, DOI: $10.1177 / 1461444817738236$.

Sharma, A.N. (2006) 'Flexibility, employment and labour market reforms in India', Economic and Political Weekly, 41(21), pp. 2078-2085.

Shinde, S. (2017) "In IT there is no job security": 25-year-old techie commits suicide in Pune', Hindustan Times, Pune, 13 July, https://www.hindustantimes.com/pune -news/job-insecurity-drives-techie-to-suicide-in-pune/story-7p1ZwoRb 5 XtrUCreZ Ve1kN.html (accessed on 14 December 2018).

SIAM (Society of Indian Automobile Manufacturers) (no date), Automotive Mission Plan 2016-26, (New Delhi: SIAM), http://www.siamindia.com/uploads/filemanager /47AUTOMOTIVEMISSIONPLAN.pdf (accessed on 14 December 2018).

Siddiqui, F. and J. Sharma (2017) 'Layoffs and shrinking job market: Is this the end of India's engineering dream?', Hindustan Times, 20 May 2017, https://www.hindustan times.com/education/layoffs-and-shrinking-job-market-is-this-the-end-of-india-s -engineering-dream/story-uWtwoE8PtslNzsfiXszMpL.html (accessed on 10 September 2018).

Srivastava, R. (2015) Structural Change and Non-Standard Forms of Employment in India, Conditions of Work and Employment Series No. 68 (Geneva: ILO), https://www.ilo .org/wcmsp5/groups/public/---ed_protect/---protrav/---travail/documents/ publication/wcms_450077.pdf (accessed on 10 September 2018). 
Srnicek, N. and A. Williams (2015) Inventing the Future. Postcapitalism and a World Without Work (New York: Verso Books).

Standing, G. (2017) Basic Income: And How we Can Make it Happen (London: Penguin). Strok, J. (2015) 'The Payoneer Freelancer Income Survey 2015', Techinfographics website, https://techinfographics.com/the-payoneer-freelancer-income-survey-2015/ (accessed on 20 August 2018).

Sundararajan, A. (2016) The Sharing Economy: The End of Employment and the Rise of Crowd-Based Capitalism (Cambridge, MA and London: MIT Press).

Surie, A. (2017) 'Tech in Work', Economic \& Political Weekly, 52(20), pp. 12-15.

Surie, A. and J. Koduganti (2016) 'The Emerging Nature of Work in Platform Economy Companies in Bengaluru, India: The Case of Uber and Ola Cab Drivers', E-Journal of International and Comparative Labour Studies, 5(3), pp. 1-30.

Tejani, S. (2016) 'Jobless Growth in India: An Investigation', Cambridge Journal of Economics, 40(3), pp. 843-870, DOI: 10.1093/cje/bevo25.

TFSSE (UN Inter-Agency Task Force on Social and Solidarity Economy) (2014) Social and Solidarity Economy and the Challenge of Sustainable Development: A Position Paper by the United Nations Inter-Agency Task Force on Social and Solidarity Economy (Geneva: TFSSE) http://unsse.org/wp-content/uploads/2014/o8/Position-Paper _TFSSE_Eng1.pdf (accessed on 10 September 2018).

Tsing, A. (2009) 'Supply chains and the human condition', Rethinking Marxism: A Journal of Economics, Culture and Society, 21(2), pp. 148-176, DOI: 10.1080/08935690902743088.

UN (United Nations) (2017) World Population Prospects: The 2017 Revision, Key Findings and Advance Tables (New York: UN Department of Economic and Social Affairs, Population Division) https://population.un.org/wpp/ (accessed on 17 September 2018).

Upadhya, C. (2016) Reengineering India. Work, Capital, and Class in an Offshore Economy (New Delhi: Oxford University Press).

Upadhya, C. and A.R. Vasavi (2008) 'Outposts of the global information economy: Work and workers in India's outsourcing industry', in C. Upadhya and A.R. Vasavi (eds.) In an Outpost of the Global Economy: Work and workers in India's information technology industry (London, New York and New Delhi: Routledge), pp. 9-49.

World Bank (no date), World Development Indicators: India, (Washington D.C.: World Bank) https://data.worldbank.org/country/india (accessed on 21August 2018).

World Bank (2018) PovcalNet: the On-line Tool for Poverty Measurement Developed by the Development Research Group of the World Bank (2007-2016), (Washington D.C.: World Bank), http://iresearch.worldbank.org/PovcalNet/povOnDemand.aspx (accessed on 21 August 2018).

Xiang, B. (2007) Global 'Body Shopping': An Indian Labor System in the Information Technology Industry (Princeton and Oxford: Princeton University Press). 